\title{
The difference between language and word
}

\section{Dilfuza KHATAMOVA ${ }^{1}$, Mohigul ALTUNDAG ${ }^{2}$}

\author{
National University of Uzbekistan named after Mirzo Ulugbek
}

\begin{tabular}{l} 
ARTICLE INFO \\
\hline Article history: \\
Received April 2021 \\
Received in revised form \\
20 April 2021 \\
Accepted 15 May 2021 \\
Available online \\
25 June 2021 \\
\hline
\end{tabular}

\section{Keywords:}

equivalence in translation, context in translation, emotional coloring in translation, metaphor in translation, textual consistency in translation.

\begin{abstract}
Although there are internal relations between languages, they differ from each other due to the peculiarities of the cultures, lifestyles and worldviews of the nations. This makes each language different from other languages in terms of its structure, as well as having its own unique structure. Due to similar factors, interpreting between two languages is a complex process. This article discusses the naturally developed differences in languages and the extent to which differences between languages affect translation performance.

2181-1415/C) 2021 in Science LLC.

This is an open access article under the Attribution 4.0 International (CC BY 4.0) license (https://creativecommons.org/licenses/by/4.0/deed.ru)
\end{abstract}

\section{Тил ва сўзнинг фарқи}

\begin{tabular}{l}
\hline Калит сўзлар: \\
таржимада \\
эквивалентлик, \\
таржимада контекст, \\
таржимада хиссий \\
буёқдорлик, \\
таржимада метафора, \\
таржимада матн \\
изчиллиги.
\end{tabular}

\begin{abstract}
АННОТАЦИЯ
Тиллар орасида ички муносабатлар бўлишига қарамай, миллатларнинг маданияти, хаёт тарзи ва дунёқарашидаги ўзига хосликлар туфайли улар бир-биридан фарқланиб туради. Бу эса хар бир тилнинг тузилишига кўра бошқа тиллардан ажралиб туришига, хамда ўзига хос тузилишга эга бўлишига олиб келади. Шу каби омиллар сабабли икки тил орасида таржимонлик қилиш мураккаб жараён саналади. Ушбу мақолада тилларда табиий равишда ривожланган фарқлар хамда тиллар орасидаги фарқларнинг таржима фаолиятига қай даражада таъсир кўрсатиши кўриб чиқилади.
\end{abstract}

\footnotetext{
${ }^{1}$ Candidate of philological Sciences, National University of Uzbekistan named after Mirzo Ulugbek. Tashkent, Uzbekistan.

2 3-course base doctoral student, National University of Uzbekistan named after Mirzo Ulugbek, Tashkent, Uzbekistan.
} 


\section{Разница между языком и словом}

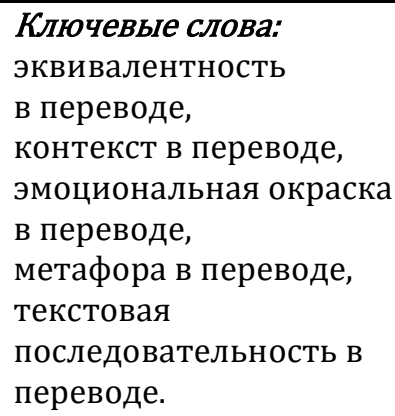

АННОТАЦИЯ

Хотя между языками существуют
отношения, они отличаются друг от друга из-за
особенностей культур, образа жизни и мировоззрения
народов. Это отличает каждый язык от других языков как с
точки зрения его структуры, так и с точки зрения
собственной уникальной структуры. Из-за схожих факторов
перевод между двумя языками - сложный процесс. В этой
статье обсуждаются естественные различия языков и
степень, в которой различия между языками влияют на
качество перевода.

Тиллар бир-бирига бутунлай бегона бўлмай, лисоний маъноларни бир тилдан бошқасига кўчириш, яъни семиотик жихатдан улар орасида ўзаро ички муносабатлар мавжудлиги туфайли таржима фаолиятини олиб бориш мумкиндир. “Тиллар орасида мавжуд деб хисобланувчи ички муносабатлар улар орасидаги ўзига хос яқинликни келтириб чиқаради. Бунга кўра, тиллар бир-бирига бегона эмас; аксинча, барча тарихий алоқалардан ташқари, мазмунан ораларида "қариндошлик" мавжуд ва бу исбот талаб қилмайдиган аксиомадир." (Бенжамин 1923, таржима, 1979 йил, сентябрь: 52)

Шу билан бирга хар бир тил ўзига хос механизмга эга мустақил тизим эканлиги боис таржима иши осон эмас ва у бир томонлама фаолият хисобланмайди. Тиллар ўртасида турли даражадаги фарқларнинг бўлиши табиий: бир томондан тиллар - фонетик (товушларга хос), синтактик (шаклий), лексик ва семантик жихатдан мустақил бўлса, бошқа томондан яъни прагматик жихатдан хам фарқланади. Биринчи гурухда санаб ўтилган жихатлар грамматик жихатдан "тил" (умумий), яъни тизим билан боғлиқ бўлса, иккинчи фарқлилик бевосита "сўз" (хусусий) яъни, тилнинг хусусий ва прагматик кўриниши билан боғлиқдир.

Муайян бир тилни тўлиқ тушуниш учун юқорида саналган жихатларнинг барчасини ўрганиш ва ўзлаштириш лозим бўлади. Хаттоки, оғзаки ёки ёзма нуқтда ўз она тилидан қийинчиликсиз ва тушунарли тарзда фойдалана оладиган киши қам, тил ва сўз борасида ўша тилда англаб етиши, тузатиши, шулар туфайли ўрганиши керак бўлган нуқталарга тез-тез дуч келадиган бўлса, бегона тилда бу нарса бир неча баробар кўпроқ мехнатни талаб қилади. Чунки бир тилнинг тизимини билиб олиш билан ўша тилнинг лексик ва прагматик хусусиятларини билиш бошқа-бошқа нарса саналади. Соссюрнинг фикрига кўра тизим, айни вақт ичида йиғилган қисмлардан таркиб топган бир бутун, яъни тартибга солинган низом бўлиб, грамматикани ташкил этади. Грамматик тадқиқотлар ичида ривож топган прагматика эса "нутқни ўзи хосил бўлган контекст ичида тадқиқ қилувчи ва шу хусусияти билан грамматикадаги асосий янгиланишни ташкил этувчи соха" (Рифат 1998: 105) саналади ва у тизимдан бошлаб турли жамият ва шахсларда фарқланувчи, хаётда, шахсий муносабатлар ва нутқларда намоён бўлувчи ифодаларни тадқиқ этади. Шу туфайли муайян бир тилнинг механизмини тўлиқ ўрганиш ва ўргатиш мумкин бўлса-да, шу тилда пайдо бўлган ва динамик кўринишга эга бўлган прагматик сохани, сўзлар қамровини тўлалигича ўрганиш 
ёки ўргатиш жуда мураккаб масаладир. Чунки бу соха айни тил тизимидан фойдаланувчи турли катта-кичик жамиятларда, турли шахслар томонидан хамда турли даврларда қўлланилади.

Шундай қилиб, тиллар орасида мавжуд бўлган шаклий фарқлар билан бирга, кенгроқ ва ўзгарувчан майдон хосил қилган мазмуний айричаликлар бир тилдан бошқасига ўгириш хақида сўз борганида алохида диққат ва эътиборни талаб қилади. Чунки шаклий хусусиятлардаги турғун қоидалар прагматик сохада ўз ўрнини - контекст аниқлангандан кейин - мухокама қилиш, изохлай олиш ва яратувчанлик қобилиятларига бўшатиб беради. “Таржима прагматикаси”да икки тил хақида сўз борар екан, бирдан ортиқ фаолият назарда тутилади. Аввало аслий матн тилида тушуниш мумкин бўлган мазмун чиқарилади (тилнинг ўз доирасидаги таржима) ва таржима тилида тушунарли эквивалентларни излаш жараёнида таржима қилинаётган тил доирасидаги сўзларга мурожаат қилинади ва шу жараёнларнинг якунида таржима вужудга келади.

Айниқса, фарқли тил оилаларига мансуб тиллар доирасидаги таржимада “ўхшашликлар”нинг учраши омадли тасодифдан бошқа нарса эмас, бундай холатларда эквивалентларни қўллаш мумкин ва хар сафар уларни янгидан ишлаб чиқиш керак бўлади. “Тил ва сўзнинг фарқи” деб ном беришимиз мумкин бўлган ушбу мавзуга фарқли тил гурухларига мансуб икки тил, яъни ўзбек ва турк тиллари мисолида ойдинлик киритишга харакат қиламиз.

Таржимада контекст ва хиссий бўёқдорлик.

Контекст тушунчаси “(..) тилнинг ташқи тузилиши билан шуғулланади ва сўзларнинг синтактик тахлилидан ташқари матнлараро контекст ва тилнинг ташқарисидаги холатни инобатга олган холда тадқиқ етади” (Кıран 2001: 175).

Контекстнинг аниқланиши сўзларнинг қандай холатларда, қайси макон ва замонда, қайси сўзлар ёки (екстралингвистик) холатларнинг ўрнида қўлланилишини очиқлайди. Контекст ифодаларини ўрганиб чиқмай туриб тўғри маъно ва мазмунни топиб бўлмайди, чунки битта сўз фарқли контекстларда турли маъно ва хиссий буёқдорлик касб етиши мумкин.

Таржимада метафора ва матн изчиллиги

Метафорик ифодалар таржимада алохида бир мавзу бўлиб, асосий ва тўғридан-тўғри маънолар билан алоқадор, баъзан еса улардан мустақил хосил бўлган метафорик маънолар маданий асосларга ега саналади; улар тил ва дунёқараш орасидаги алоқани очиқлаб берувчи ифодалардир.

Таржимада қисқа ифодалар ва шархлар

Нутқ жараёнида тўлиқсиз ифодаларга тез-тез мурожаат қилинади. Бир тил доирасида хам кўп холларда чала ёки нотўғри маънони келтириб чиқарадиган бу холатга, табиийки, таржимада кўпроқ эътибор қаратиш лозим бўлади.

Хулоса ўрнида айтиш мумкинки, аслий матн тилидаги қисқа ифода шаклга зарар бермайдиган тарзда, аммо таржима тилида маънони тўлиқ билдирмай қолгандагина ва фақат кераклича хажмда шархланиши керак.

Иборалар ва қолиплашган бирикмалар

Хар бир тилнинг луғат бойлигида ишлатилишига кўра маъноси ўзгармайдиган иборалар ва қолиплашган бирикмалар мавжуд. Ибора “муайян бир тушунчани, муайян туйғу ёки холатни ифодалаш учун бирдан ортиқ сўзларни бирга қўллаш, айрим холларда еса бир сўзни кўчма маънода қўллаш орқали хосил 
бўладиган ифода” (Аксан 1982: 37), қолиплашган бирикма еса “жамият аъзолари ўртасидаги муносабатлар жараёнида ишлатилиши одатий тусга кириб қолган сўзлар мажмуи"дир (Аксан 1996: 34). Хар бир тил ва маданият, кўплаб таъсирчан ва рамзий қарама-қаршиликларга, ўхшатиш ва изохларга мурожаат қилади. Шу жихатдан қаралганда хар бир тилнинг ўзига хослиги ва ранг-баранг ифода тарзлари борлиги хеч кимга сир емас. Бутунлай тўғридан-тўғри маъно устига қурилган, мантиққа асосланган ва қуруқ жонли мулоқот тилининг мавжуд бўлиши имконсиз. Таржима хақида гап борганда маънолар таржимаси асосий планда туради ва афсуски, кўп холларда бир тилга хос бўлган хусусиятларни бошқа бир тилга ўз холатича ўгиришнинг имкони бўлмайди. Аммо тўғридан-тўғри маъно билан бирга хазил, киноя, мажозий тасвирлаш вб.га асосланган ибора ва қолиплашган бирикмалар таржимасида бу хусусиятлар таржима тилининг луғат бойлигидан қидирилиши лозим. Шу ўринда ибора ва қолиплашган бирикмаларга контекстнинг таъсири жуда кам бўлишини эслатиб ўтиш жоиз. Қолиплашган бирикмалар қўлланганда ўхшаш маъно ва мазмунни билдириб, уларни таржима қилиш осондек кўринса-да, бунда диққат қаратилиши керак бўлган бир хусус мавжуд.

\section{ХУЛОСА}

Ушбу мақолада икки тил орасида маданият, дунёқараш ва хаёт тарзи, дунёни англаш ва тасвирлаш, маъно бериш сингари жуда кўп омилларга боғлиқ холда тилларда табиий равишда юзага чиқадиган фарқлар хақида фикр юритиб, улардан бир нечтасини мисоллар билан изохлашга харакат қилинди. Тиллар уртасида мавжуд бўлган турли фарқларнинг таржима фаолиятига, таржимада қабул қилиниши мумкин бўлган муқобилларга қанчалик таъсир қилишини мухокама қилиб, таржиманинг турли босқичларда, турли вазиятларда қандай ёндашувларни талаб қилиши аниқланди.

- Биринчи маъно ва метафорик маъно орасидаги фарқни кўздан қочирмаслик;

- Тўлиқсиз ифодаларнинг таржима тилига айни шаклда ўгирилиши холатида таржима тили ўқувчиси учун маънонинг ёпиқ, тушунарсиз холатга келиб қолмаслигини таъминлаш;

- Керакли вазиятларда шархларга мурожаат қилиш;

- Бир ифоданинг аслий матн тилида берадиган таъсирини ўгира олиш;

- Тил сатхларига имкон қадар содиқ қолиш;

- Хиссий бўёқдорликни ўзгаришсиз ўгириш.

\section{ФОЙДАЛАНИЛГАН АДАБИЁТЛАР РЎЙХАТИ:}

1. Ғайбулла Саломов “Таржима назариясига кириш”. Тошкент: Ўқитувчи (1978).

2. Аксан Доған “Türkçenin sözvarliği”Анкара: Янгин йай (1996).

3. Аксан Доған "Her yönüyle dil” 3-жилд. Анкара: Турк дил куруму (1982).

4. Бенжамин Волтер “Çevirmenin görevi” Мадагият вазирлиги 1979. - Б. 49-60.

5. Киран Зейнел “Dilbimine giriş” Анкара: сечкин яй (2001).

6. Рифат Мехмет "ХX Yüzyılda dilbilim ve göstergebilim kuramları" 1-жилд. Истанбул: ЙКЙ (1998). 